\title{
Preparation and electrochemical properties of layer-structured $\mathrm{LiNi}_{1 / 3} \mathrm{Co}_{1 / 3} \mathrm{Mn}_{1 / 3-y} \mathrm{Al}_{y} \mathrm{O}_{2}$
}

\author{
Yu-Kai Lin, Chung-Hsin Lu* \\ Electronic and Electro-Optical Ceramics Laboratory, Department of Chemical Engineering, National Taiwan University, Taipei, Taiwan, ROC
}

\section{A R T I C L E I N F O}

\section{Article history:}

Received 27 June 2008

Received in revised form 12 August 2008

Accepted 12 August 2008

Available online xxx

\section{Keywords:}

Layered structure

Sol-gel

Cathode materials

Lithium-ion batteries

\begin{abstract}
A B S T R A C T
Layer-structured $\mathrm{LiNi}_{1 / 3} \mathrm{Co}_{1 / 3} \mathrm{Mn}_{1 / 3-y} \mathrm{Al}_{y} \mathrm{O}_{2}$ has been synthesized via a sol-gel method. The lattice constants of $\mathrm{LiNi}_{1 / 3} \mathrm{Co}_{1 / 3} \mathrm{Mn}_{1 / 3-y} \mathrm{Al}_{y} \mathrm{O}_{2}$ decrease with the concentration of aluminum ions. XANES analysis further confirms that the valence of cobalt ion is $3+$, and that of $\mathrm{Ni}$ is between $2+$ and $3+$ in $\mathrm{LiNi}_{1 / 3} \mathrm{Co}_{1 / 3} \mathrm{Mn}_{1 / 3-y} \mathrm{Al}_{y} \mathrm{O}_{2}$. With doping aluminum ions, the redox centers for the electrochemical reaction change from nickel ions alone to both nickel and cobalt ions. The amounts of de-intercalatable lithium ions are affected by the concentration of aluminum ions; however, the extracting efficiency of lithium ions is improved by doping aluminum ions. Among all the samples, $\mathrm{LiNi}_{1 / 3} \mathrm{Co}_{1 / 3} \mathrm{Mn}_{0.23} \mathrm{Al}_{0.1} \mathrm{O}_{2}$ exhibits the best capacity retention and the least irreversible capacity.
\end{abstract}

() 2008 Elsevier B.V. All rights reserved.

\section{Introduction}

In recent years, the use of $\mathrm{LiNi}_{1 / 3} \mathrm{Co}_{1 / 3} \mathrm{Mn}_{1 / 3} \mathrm{O}_{2}$ as cathode material in lithium-ion batteries has been investigated extensively because of its high capacity, good thermal stability, and relatively low cost with respect to $\mathrm{LiCoO}_{2}$ [1]. In this type of lithium insertion system, the valences of nickel, cobalt, and manganese ions are $2+, 3+$, and $4+$, respectively $[2,3]$. When $\mathrm{LiNi}_{1 / 3} \mathrm{Co}_{1 / 3} \mathrm{Mn}_{1 / 3} \mathrm{O}_{2}$ cell is cycled between $2.5 \mathrm{~V}$ and $4.5 \mathrm{~V}, \mathrm{Ni}^{2+} / \mathrm{Ni}^{4+}$ redox pairs exist predominantly during the electrochemical reaction [3]. However, the valences of cobalt ions do not change in this specific voltage range. It is assumed that the electrochemical performance can be modified if the redox centers not only locate at nickel ions but also at cobalt ions. To investigate the electrochemical behaviors with cobalt ions also undergoing charge transfer reaction, aluminum ion is chosen as a dopant due to its fixed valence. For a layer-structured system, aluminum doping is an effective way to improve cycle life and thermal stability [4], as well as to reduce cation mixing and irreversible capacity [5].

In this study, we developed a sol-gel process to synthesize layerstructured $\mathrm{LiNi}_{1 / 3} \mathrm{Co}_{1 / 3} \mathrm{Mn}_{1 / 3-y} \mathrm{Al}_{y} \mathrm{O}_{2}(0 \leq y \leq 1 / 3)$. Aluminum ions were used to substitute manganese ions in $\mathrm{LiNi}_{1 / 3} \mathrm{Co}_{1 / 3} \mathrm{Mn}_{1 / 3} \mathrm{O}_{2}$. The sol-gel method was widely adopted to synthesize compounds with multiple components due to high homogeneity of

\footnotetext{
* Corresponding author. Tel.: +8862 23651428; fax: +886223623040.

E-mail address: chlu@ccms.ntu.edu.tw (C.-H. Lu).
}

starting materials and large surface area of obtained powders [6,7], and this method was also expected to be beneficial to electrochemical reaction. The average valence of nickel ions in $\mathrm{LiNi}_{1 / 3} \mathrm{Co}_{1 / 3} \mathrm{Mn}_{1 / 3-y} \mathrm{Al}_{y} \mathrm{O}_{2}$ was expected to change gradually from $2+$ to $3+$ with an increase in $y$ value. The number of rechargeable lithium ions in $\mathrm{LiNi}_{1 / 3} \mathrm{Co}_{1 / 3} \mathrm{Mn}_{1 / 3-y} \mathrm{Al}_{y} \mathrm{O}_{2}$ would be limited by the fraction of transition metal ions [8]. In this study, the preparation parameters of sol-gel derived $\mathrm{LiNi}_{1 / 3} \mathrm{Co}_{1 / 3} \mathrm{Mn}_{1 / 3} \mathrm{O}_{2}$ were discussed to facilitate the synthesis of $\mathrm{LiNi}_{1 / 3} \mathrm{Co}_{1 / 3} \mathrm{Mn}_{1 / 3-y} \mathrm{Al}_{y} \mathrm{O}_{2}$ powders. The electrochemical characteristics of $\mathrm{LiNi}_{1 / 3} \mathrm{Co}_{1 / 3} \mathrm{Mn}_{1 / 3-y} \mathrm{Al}_{y} \mathrm{O}_{2}$ tested between $2.5 \mathrm{~V}$ and $5.0 \mathrm{~V}$ were also investigated.

\section{Experimental}

Lithium nitrate (nakalai, 98\%), nickel nitrate (Wako, 98\%), cobalt nitrate (nakalai, 97\%), manganese nitrate (nakalai, 98\%), and aluminum nitrate (Sigma-Aldrich, 98\%) were used as the starting materials, and polyvinyl alcohol (PVA, nakalai) served as the organic fuel. Proper amounts of the compounds containing metal cations, according to the stoichiometry of $\mathrm{LiNi}_{1 / 3} \mathrm{Co}_{1 / 3} \mathrm{Mn}_{1 / 3-y} \mathrm{Al}_{y} \mathrm{O}_{2}$ with $\mathrm{y}$ ranging from 0 to $1 / 3$, were dissolved in de-ionic water to form $0.5 \mathrm{M}$ aqueous solution. PVA, with its amount carefully calculated so that the effective total valency ratio $\Phi$ could be equal to 1.0 [9], was added into the above aqueous solution. After overnight stirring, the well-mixed solution was heated at $350^{\circ} \mathrm{C}$ to form gels. The gels were calcined at elevated temperatures in air.

X-ray diffraction (XRD) analysis (MAC Science, Tokyo, Japan) using nickel-filtered $\mathrm{Cu}-\mathrm{K} \alpha$ radiation was performed to iden- 


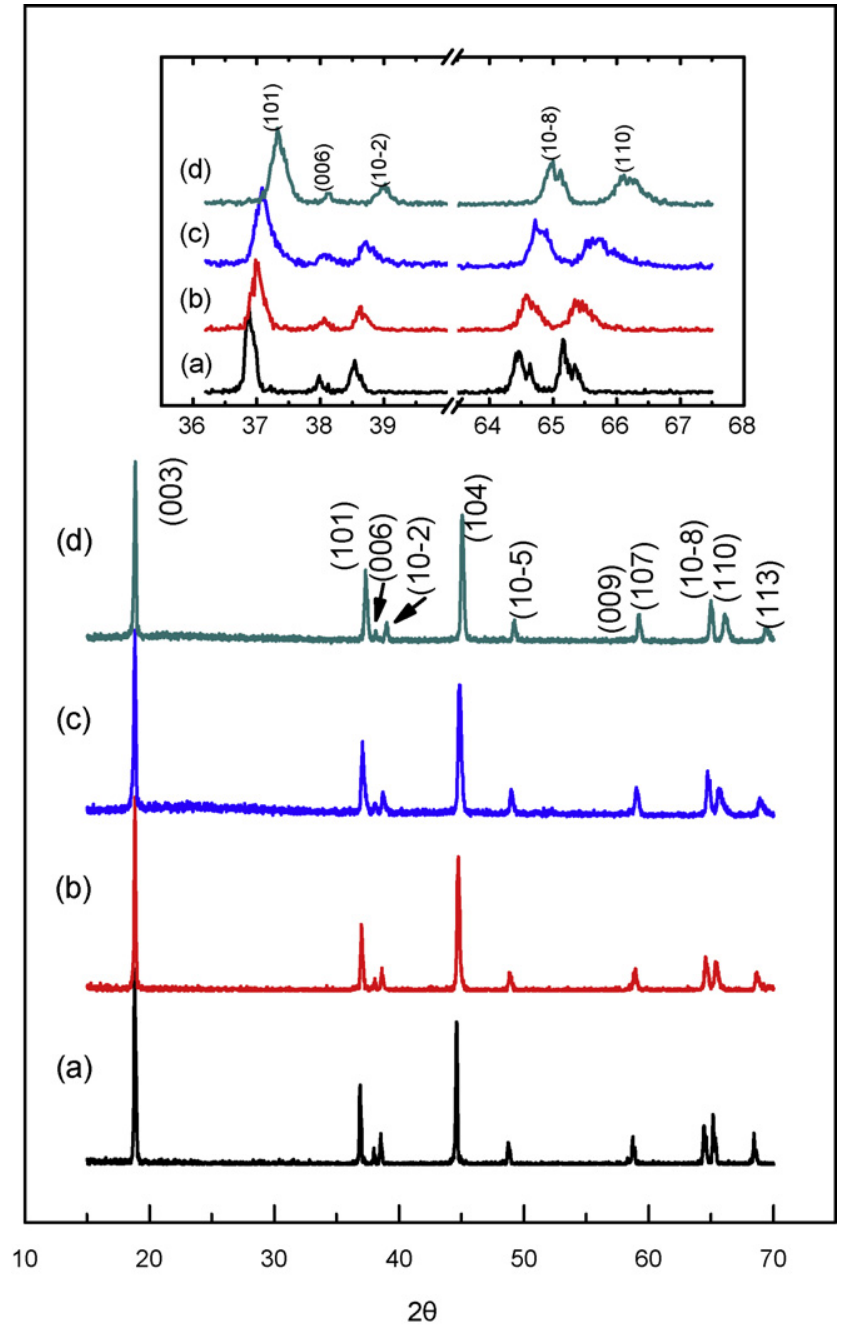

Fig. 1. XRD patterns of $\mathrm{LiNi}_{1 / 3} \mathrm{Co}_{1 / 3} \mathrm{Mn}_{1 / 3-y} \mathrm{Al}_{y} \mathrm{O}_{2}$ calcined at $900{ }^{\circ} \mathrm{C}$. (a) $y=0$, (b) $y=0.1$, (c) $y=0.2$, and (d) $y=1 / 3$.

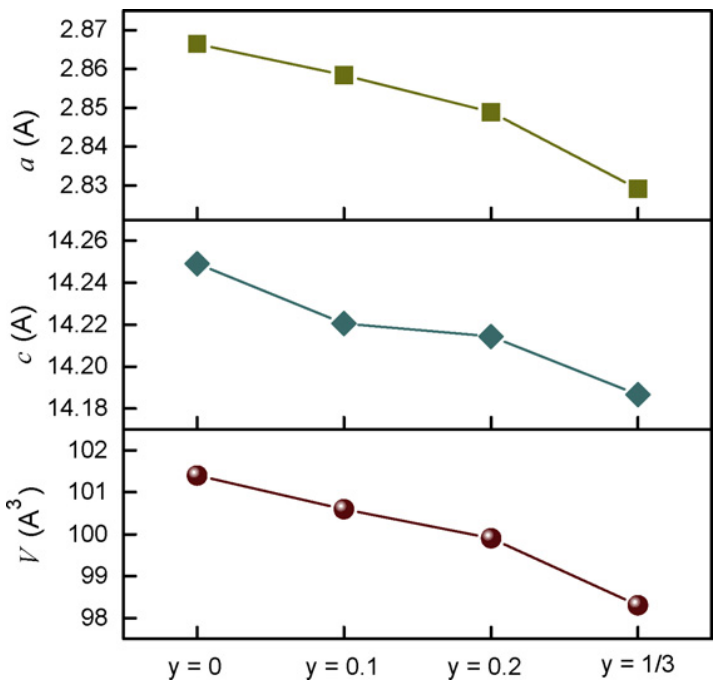

Fig. 2. Lattice parameters of $\mathrm{LiNi}_{1 / 3} \mathrm{Co}_{1 / 3} \mathrm{Mn}_{1 / 3-y} \mathrm{Al}_{y} \mathrm{O}_{2}$.
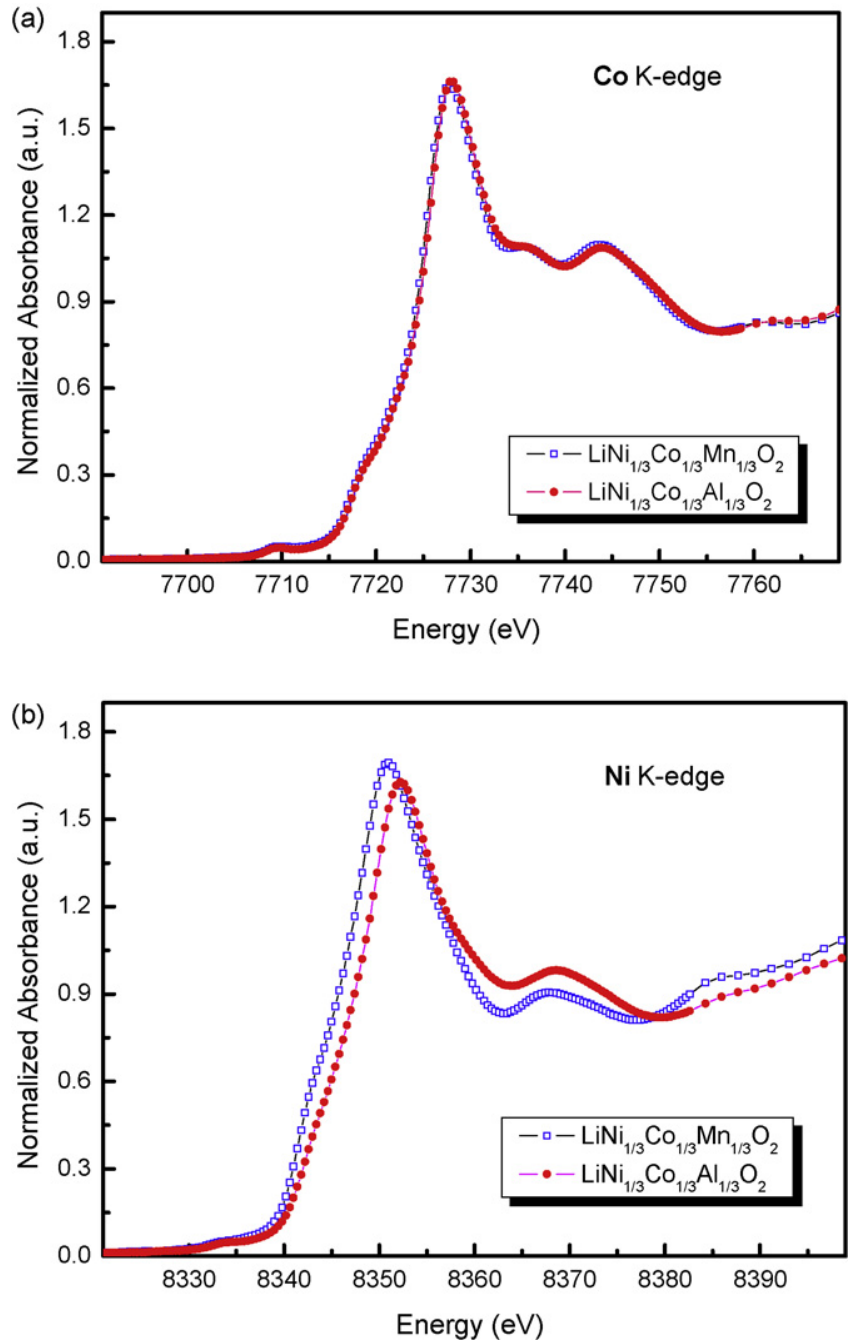

Fig. 3. Normalized XANES spectra for $\mathrm{LiNi}_{1 / 3} \mathrm{Co}_{1 / 3} \mathrm{Al}_{1 / 3} \mathrm{O}_{2}$ at (a) Co K-edge and (b) $\mathrm{N}$ K-edge compared with the spectra of $\mathrm{LiNi}_{1 / 3} \mathrm{Co}_{1 / 3} \mathrm{Mn}_{1 / 3} \mathrm{O}_{2}$.

tify the crystalline phase. The morphology and particle size of the obtained powders were examined via scanning electron microscopy (SEM) (Model S-2400, Hitachi). The electrochemical characteristics of the sol-gel derived powders were investigated using coin cells. The cathode composite was comprised of $85 \mathrm{wt} \%$ of $\mathrm{LiNi}_{1 / 3} \mathrm{Co}_{1 / 3} \mathrm{Mn}_{1 / 3-y} \mathrm{Al}_{y} \mathrm{O}_{2}$ powders calcined at $800^{\circ} \mathrm{C}$ for $3 \mathrm{~h}, 5 \mathrm{wt} \%$ of KS6 graphite, $2 \mathrm{wt} \%$ of super-P carbon black, $8 \mathrm{wt} \%$ of binder (polyvinylidene fluoride, PVdF), and using NMP ( $n$-methyl pyrrolidone) as a solvent. The fabricated cathodes were dried in a vacuum oven overnight to remove excess NMP. Lithium foil was utilized as the anode, and the electrolyte solution was composed of $1 \mathrm{M}$ $\mathrm{LiPF}_{6}$ dissolved in the mixture of ethylene carbonate (EC)-diethyl carbonate (DEC) (with a volume ratio of 1:1). The 2032-type coin cells were assembled in a glove box filled with high-purity argon, and the water concentration in this box was precisely controlled to be less than $1 \mathrm{ppm}$. The cells were galvanostatically cycled at the current density of $20 \mathrm{mAg}^{-1}$ within the potential range of $2.5-4.5 \mathrm{~V}$.

X-ray absorption spectroscopy (XAS) was undertaken in transition mode at beam line BL-17C at National Synchrotron Radiation Research Center (NSRRC) in Hsinchu, Taiwan. The storage ring was operated with the energy of $1.5 \mathrm{GeV}$ and a current between $100 \mathrm{~mA}$ and $200 \mathrm{~mA}$. A Si (111) double-crystal monochromator was employed for energy selection. High-order harmonic contam- 
(a)

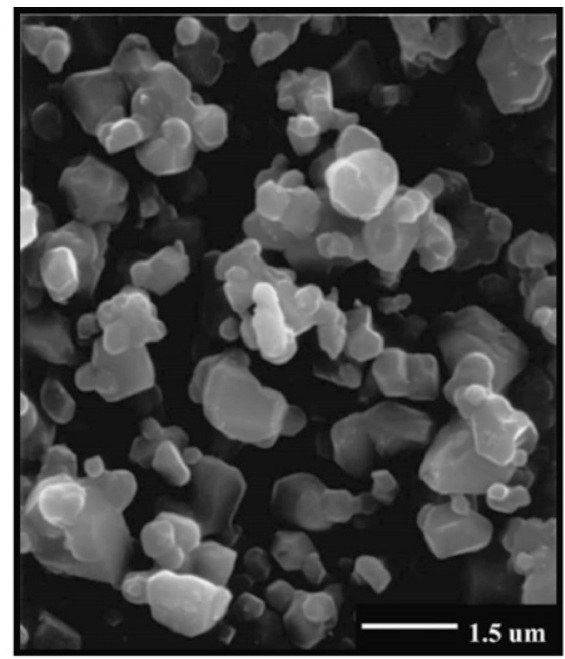

(c)

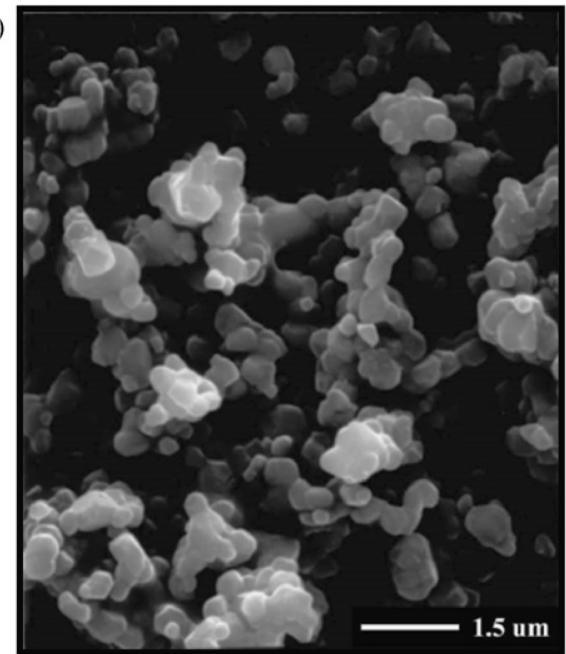

(b)

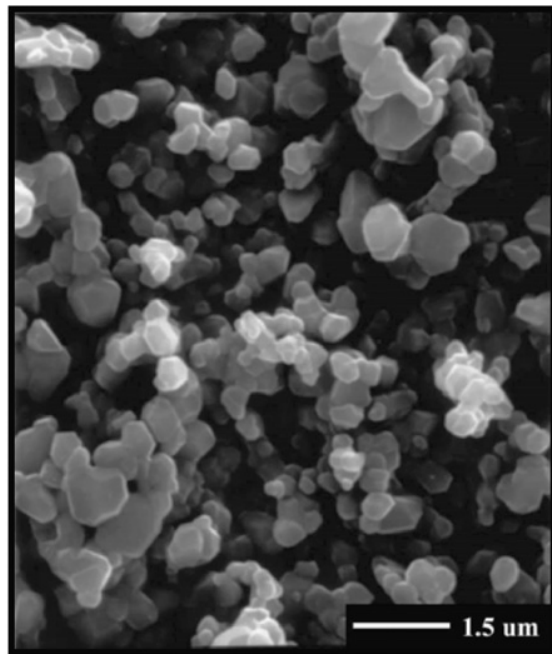

(d)

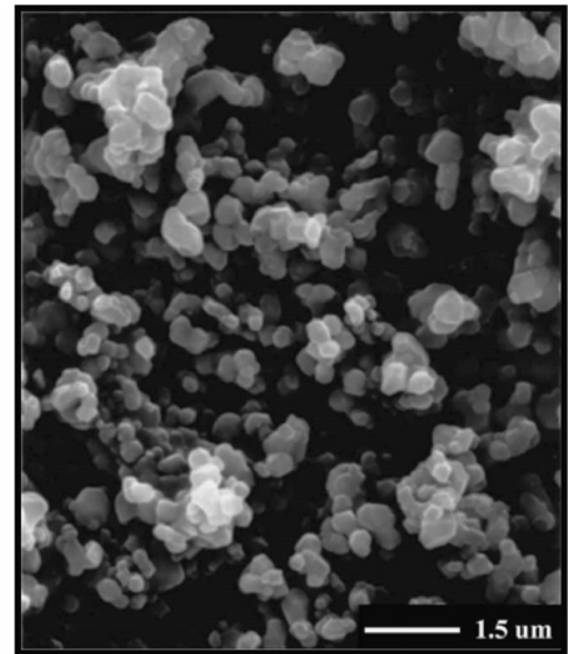

Fig. 4. Scanning electron microscopy (SEM) images of $\mathrm{LiNi}_{1 / 3} \mathrm{Co}_{1 / 3} \mathrm{Mn}_{1 / 3-y} \mathrm{Al}_{y} \mathrm{O}_{2}$ calcined at $900{ }^{\circ} \mathrm{C}$. (a) $y=0$, (b) $y=0.1$, (c) $y=0.2$, and (d) $y=1 / 3$.

ination was rejected by mirrors. The intensities of the incident and transmitted beams were measured using gas ionization chambers.

\section{Results and discussion}

\subsection{Preparation of $\mathrm{LiNi}_{1 / 3} \mathrm{Co}_{1 / 3} \mathrm{Mn}_{1 / 3-y} \mathrm{Al}_{y} \mathrm{O}_{2}$ via the sol-gel process}

Fig. 1 illustrates the XRD patterns of $\mathrm{LiNi}_{1 / 3} \mathrm{Co}_{1 / 3} \mathrm{Mn}_{1 / 3-y} \mathrm{Al}_{y} \mathrm{O}_{2}$ $(0 \leq y \leq 1 / 3)$ calcined at $900^{\circ} \mathrm{C}$ in air for $10 \mathrm{~h}$. As shown in Fig. 1 , the samples with $y=0$ to $1 / 3$ are the single phase having an $\alpha$ $\mathrm{NaFeO}_{2}$ structure, suggesting that $\mathrm{LiNi}_{1 / 3} \mathrm{Co}_{1 / 3} \mathrm{Mn}_{1 / 3-y} \mathrm{Al}_{y} \mathrm{O}_{2}$ was successfully prepared via the sol-gel method. Based on the inset of Fig. 1, with increasing content of aluminum ions, the (006) diffraction line shifts toward lower diffraction angles and the (110) line oppositely shifts toward higher diffraction angles. This kind of shifting results in a clear split of $(006) /(102)$ and $(108) /(110)$ peaks. Selective line broadening is observed especially for the (110) and (113) lines as the aluminum content increases, suggesting microscopic stress on the basal plane [8].

Fig. 2 illustrates the lattice parameters $a, c$, and unit cell volume $V$, as a function of $y$ in $\mathrm{LiNi}_{1 / 3} \mathrm{Co}_{1 / 3} \mathrm{Mn}_{1 / 3-y} \mathrm{Al}_{y} \mathrm{O}_{2}$. These parameters were obtained by the least squares method. Substituting manganese ions by aluminum ions in $\mathrm{LiNi}_{1 / 3} \mathrm{Co}_{1 / 3} \mathrm{Mn}_{1 / 3} \mathrm{O}_{2}$ leads to a decrease in both $a$ and $c$ parameters. Consequently, the unit cell volume also decreases from $101.4 \AA$ to $98.3 \AA$ as y increases from 0 to $1 / 3$. The lattice parameters for the end members of $\mathrm{LiNi}_{1 / 3} \mathrm{Co}_{1 / 3} \mathrm{Mn}_{1 / 3-y} \mathrm{Al}_{y} \mathrm{O}_{2}$ are $a=2.866 \AA$ and $c=14.249 \AA$ (unit cell volume $=101.4 \AA^{3}$ ) for $\mathrm{LiNi}_{1 / 3} \mathrm{Co}_{1 / 3} \mathrm{Mn}_{1 / 3} \mathrm{O}_{2}$ versus $a=2.829 \AA$ and $c=14.187 \AA$ ( unit cell volume $=98.3 \AA^{3}$ ) for $\mathrm{LiNi}_{1 / 3} \mathrm{Co}_{1 / 3} \mathrm{Al}_{1 / 3} \mathrm{O}_{2}$. The decrease in the lattice parameters could be attributed to an increase in the oxidation state of nickel ions, as well as the substitution of manganese ions by aluminum ions in $\mathrm{LiNi}_{1 / 3} \mathrm{Co}_{1 / 3} \mathrm{Mn}_{1 / 3} \mathrm{O}_{2}$.

To further determine the valences of transition metal ions in $\mathrm{LiNi}_{1 / 3} \mathrm{Co}_{1 / 3} \mathrm{Mn}_{1 / 3-y} \mathrm{Al}_{y} \mathrm{O}_{2}$, the X-ray absorption near-edge structure (XANES) of $\mathrm{LiNi}_{1 / 3} \mathrm{Co}_{1 / 3} \mathrm{Mn}_{1 / 3} \mathrm{O}_{2}$ and $\mathrm{LiNi}_{1 / 3} \mathrm{Co}_{1 / 3} \mathrm{Al}_{1 / 3} \mathrm{O}_{2}$ were analyzed to obtain information about the valence state of the absorbing atom. The $\mathrm{Co}$ and Ni K-edge XANES spectra of $\mathrm{LiNi}_{1 / 3} \mathrm{Co}_{1 / 3} \mathrm{Mn}_{1 / 3} \mathrm{O}_{2}$ and $\mathrm{LiNi}_{1 / 3} \mathrm{Co}_{1 / 3} \mathrm{Al}_{1 / 3} \mathrm{O}_{2}$ are depicted in Fig. 3(a) and (b), respectively. The valences of transition metal ions, nickel, cobalt, and manganese ions, in $\mathrm{LiNi}_{1 / 3} \mathrm{Co}_{1 / 3} \mathrm{Mn}_{1 / 3} \mathrm{O}_{2}$ were reported to be $2+, 3+$, and $4+$, respectively $[2,3]$. Hence, the XANES spectra of $\mathrm{LiNi}_{1 / 3} \mathrm{Co}_{1 / 3} \mathrm{Mn}_{1 / 3} \mathrm{O}_{2}$ are used as the reference. The metal K-edge XANES spectra originate from symmetry-allowed transitions of the $1 \mathrm{~s}$ core electron of the metal to excited vacant bound state. The weak pre-edge absorption is due to formally electric dipole-forbidden transition of the $1 \mathrm{~s}$ electron to an unoccupied 3d orbital [10]. Herein, the peaks at $7709.4 \mathrm{eV}$ and $8333.4 \mathrm{eV}$ are assigned to $\mathrm{Co}$ and $\mathrm{Ni}$, respectively. For $\mathrm{LiNi}_{1 / 3} \mathrm{Co}_{1 / 3} \mathrm{Al}_{1 / 3} \mathrm{O}_{2}$, the energy position of the absorption edge for Co almost over- 


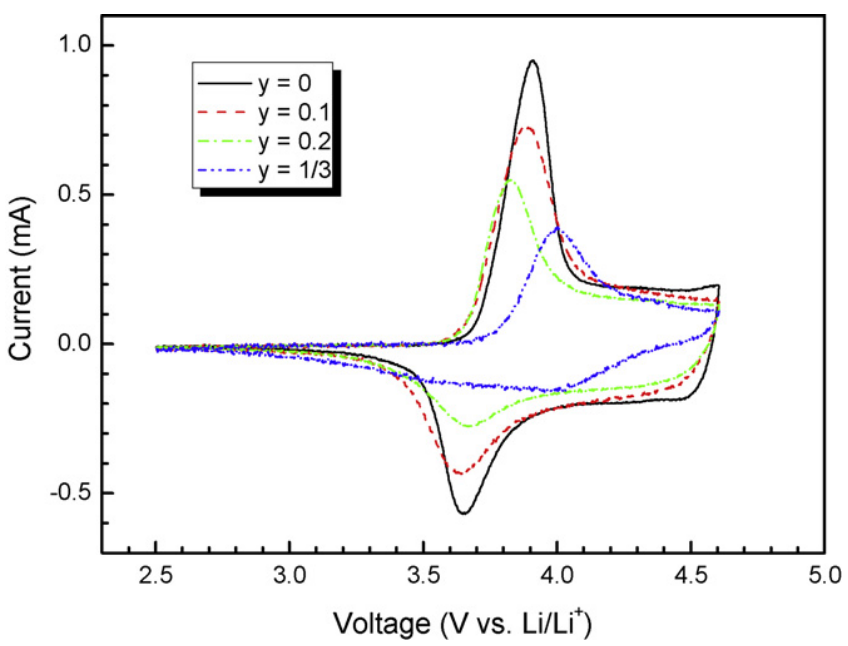

Fig. 5. Cyclic voltammogram of $\mathrm{Li} / \mathrm{LiNi}_{1 / 3} \mathrm{Co}_{1 / 3} \mathrm{Mn}_{1 / 3-y} \mathrm{Al}_{y} \mathrm{O}_{2}$ cells between $2.5 \mathrm{~V}$ and $4.6 \mathrm{~V}$ at a scan rate of $100 \mu \mathrm{A} / \mathrm{s}$.

laps with that for $\mathrm{LiNi}_{1 / 3} \mathrm{Co}_{1 / 3} \mathrm{Mn}_{1 / 3} \mathrm{O}_{2}$, and the X-ray absorption curve is also similar to that of the reference sample. The results indicate that the valence states of cobalt ions are the same (3+) in both $\mathrm{LiNi}_{1 / 3} \mathrm{Co}_{1 / 3} \mathrm{Al}_{1 / 3} \mathrm{O}_{2}$ and $\mathrm{LiNi}_{1 / 3} \mathrm{Co}_{1 / 3} \mathrm{Mn}_{1 / 3} \mathrm{O}_{2}$, and the local geometry and electronic structure around cobalt atoms remain unchanged. However, the energy position for $\mathrm{Ni}$ absorber in $\mathrm{LiNi}_{1 / 3} \mathrm{Co}_{1 / 3} \mathrm{Al}_{1 / 3} \mathrm{O}_{2}$ lies at higher energy than that in $\mathrm{LiNi}_{1 / 3} \mathrm{Co}_{1 / 3} \mathrm{Mn}_{1 / 3} \mathrm{O}_{2}$, indicating that the oxidation state of nickel ions in $\mathrm{LiNi}_{1 / 3} \mathrm{Co}_{1 / 3} \mathrm{Al}_{1 / 3} \mathrm{O}_{2}$ is higher than that in the reference. Therefore, the valence of nickel ions in $\mathrm{LiNi}_{1 / 3} \mathrm{Co}_{1 / 3} \mathrm{Al}_{1 / 3} \mathrm{O}_{2}$ could be between $2+$ and $3+$ due to the substitution of manganese ions by aluminum ions.

The microstructures of $\mathrm{LiNi}_{1 / 3} \mathrm{Co}_{1 / 3} \mathrm{Mn}_{1 / 3-y} \mathrm{Al}_{y} \mathrm{O}_{2}$ powders calcined at $900^{\circ} \mathrm{C}$ are illustrated in Fig. 4. For the sample with $y=0$, the particle size is about $1 \mu \mathrm{m}$. With increasing amount of aluminum ions doped, the particles size of the prepared powders slightly decreases. As shown in Fig. 4, well-dispersed powders were obtained via the sol-gel process. Fig. 5 depicts the CV curves of $\mathrm{LiNi}_{1 / 3} \mathrm{Co}_{1 / 3} \mathrm{Mn}_{1 / 3-y} \mathrm{Al}_{y} \mathrm{O}_{2}$ at a scanning rate of $100 \mu \mathrm{V} / \mathrm{s}$. A pair of redox peaks, corresponding to lithium intercalation and deintercalation reactions, is found in the voltage range of $3.0-4.6 \mathrm{~V}$. The anodic scans for all four samples show a distinct oxidation peak; however, the potential positions shift with $y$. The oxidation peaks are mainly resulted from the oxidation of nickel ions, $\mathrm{Ni}^{2+}$ for $y \leq 0.2$ and $\mathrm{Ni}^{3+}$ for $y=1 / 3$, respectively [2,11]. The sharp curves are due to electron transfer occurring in $\mathrm{Ni}^{2+}$ and $\mathrm{Ni}^{3+}$, as these transferred electrons are unpaired and located at nickel $e_{g}$ band. For lithium intercalation reaction process, there is also a distinct reduction peak except for $y=1 / 3 . \mathrm{LiNi}_{1 / 3} \mathrm{Co}_{1 / 3} \mathrm{Al}_{1 / 3} \mathrm{O}_{2}$ is found to have two reduction peaks with the major one centering at about $4.03 \mathrm{~V}$ and the minor broad one at around $3.7 \mathrm{~V}$, which are responsible for $\mathrm{Co}^{3+} / \mathrm{Co}^{4+}$ pair at high voltage and $\mathrm{Ni}^{3+} / \mathrm{Ni}^{4+}$ pair at low voltage.

\subsection{Electrochemical properties of the sol-gel derived $\mathrm{LiNi}_{1 / 3} \mathrm{Co}_{1 / 3} \mathrm{Mn}_{1 / 3-y} \mathrm{Al}_{y} \mathrm{O}_{2}$ powders}

The charge/discharge performance and cycling behaviors of $\mathrm{LiNi}_{1 / 3} \mathrm{Co}_{1 / 3} \mathrm{Mn}_{1 / 3-y} \mathrm{Al}_{y} \mathrm{O}_{2}$ were studied, and the results are illustrated in Fig. 6. The range of operation voltage was set from $2.5 \mathrm{~V}$ to $4.5 \mathrm{~V}$ with the current density of $40 \mathrm{mAh} / \mathrm{g}$ at room temperature. As shown in Fig. 6, both the first charge and discharge curves exhibit smooth and monotonous voltage profiles for all samples. During the charging process, each sample shows a distinct plateau. The
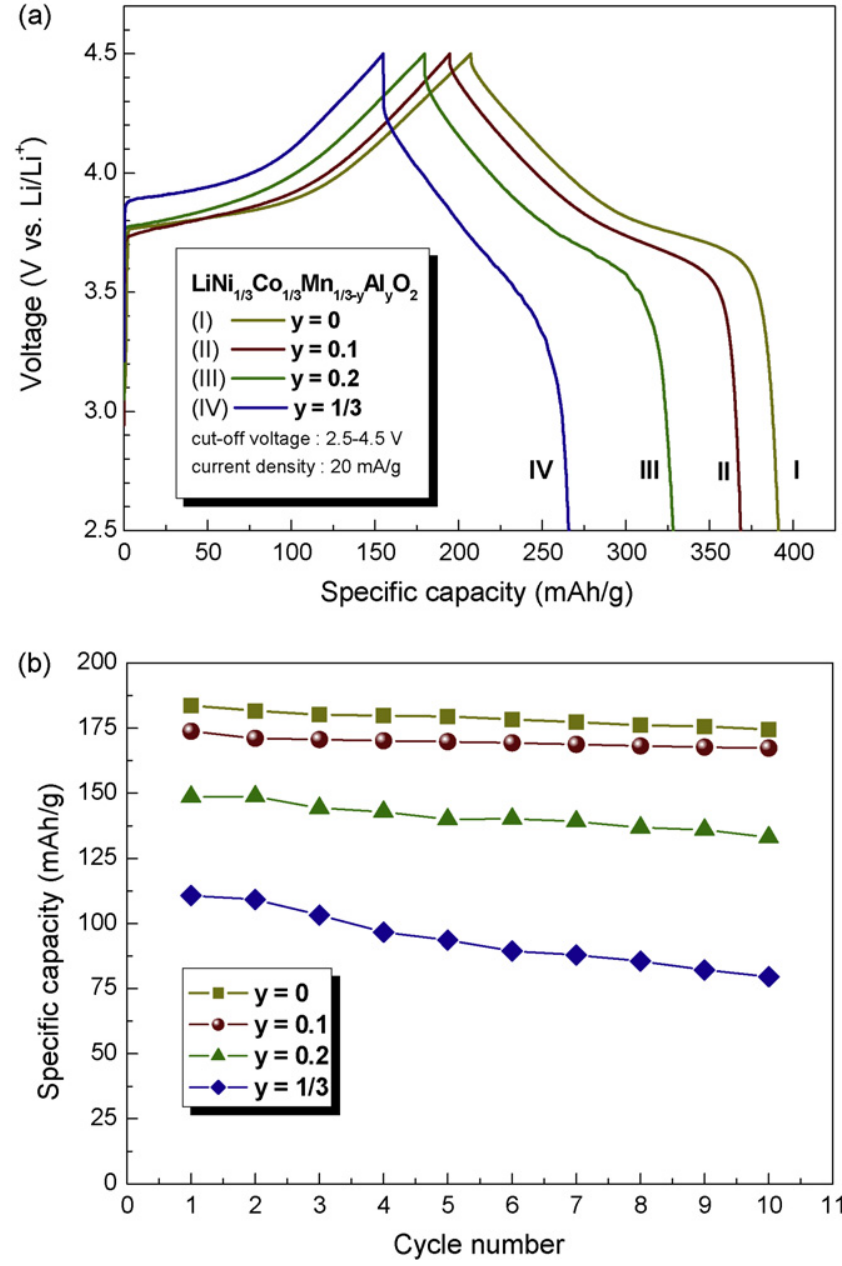

Fig. 6. (a) First charge/discharge curves and (b) specific capacity vs. cycle number for $\mathrm{Li} / \mathrm{LiNi}_{1 / 3} \mathrm{Co}_{1 / 3} \mathrm{Mn}_{1 / 3-y} \mathrm{Al}_{y} \mathrm{O}_{2}$ cells cycling between $2.5 \mathrm{~V}$ and $4.5 \mathrm{~V}$.

plateau for $y=1 / 3$ appears at markedly higher voltage than that for $y \leq 0.2$. On the other hand, the discharge plateau diminishes gradually to become unobvious with increasing concentration of aluminum ions. This is considered that doping aluminum ions lead to slow kinetics of charge compensation and relaxed redox reaction [12].

For $\mathrm{LiNi}_{1 / 3} \mathrm{Co}_{1 / 3} \mathrm{Mn}_{1 / 3} \mathrm{O}_{2}$ as shown in Fig. 6(a), the initial charge capacity between $2.5 \mathrm{~V}$ and $4.5 \mathrm{~V}$ is $207.2 \mathrm{mAh} / \mathrm{g}$ ( $74 \%$ of the theoretical value). The irreversible capacity is calculated to be $11.4 \%$ $(23.6 \mathrm{mAh} / \mathrm{g})$. The initial charge capacity for the sample with $y=0.1$ is $194.6 \mathrm{mAh} / \mathrm{g}$, which consists with our expectation in light of limited number of extractable lithium ions [13]. The fraction of deintercalated lithium ions for the sample with $y=0.1$ is $75.5 \%$, slightly higher than that of $\mathrm{LiNi}_{1 / 3} \mathrm{Co}_{1 / 3} \mathrm{Mn}_{1 / 3} \mathrm{O}_{2}$. In addition, this sample exhibits a smaller irreversible capacity $\left(20.84 \mathrm{mAh} \mathrm{g}^{-1}\right)$ than the undoped sample. This indicates that partial doping of aluminum ions can improve the charge transfer efficiency and reduce the irreversible capacity. For the samples with $y=0.2$ and $1 / 3$, the fractions of de-intercalated lithium ions are both greater than $75 \%$ even though the initial charge capacities decrease. As shown in Fig. 6(b), the sample with $y=0.1$ exhibits the least capacity fadeaway (about 3.7\%) after ten cycles. Aluminum ions have been confirmed as an effective dopant for stabilizing the layered structure $[8,14]$ not only by enhancing structural stability during cycling, but also by reducing cation mixing to facilitate better capacity retention. Therefore, the improvement in charge transfer efficiency and cycle 

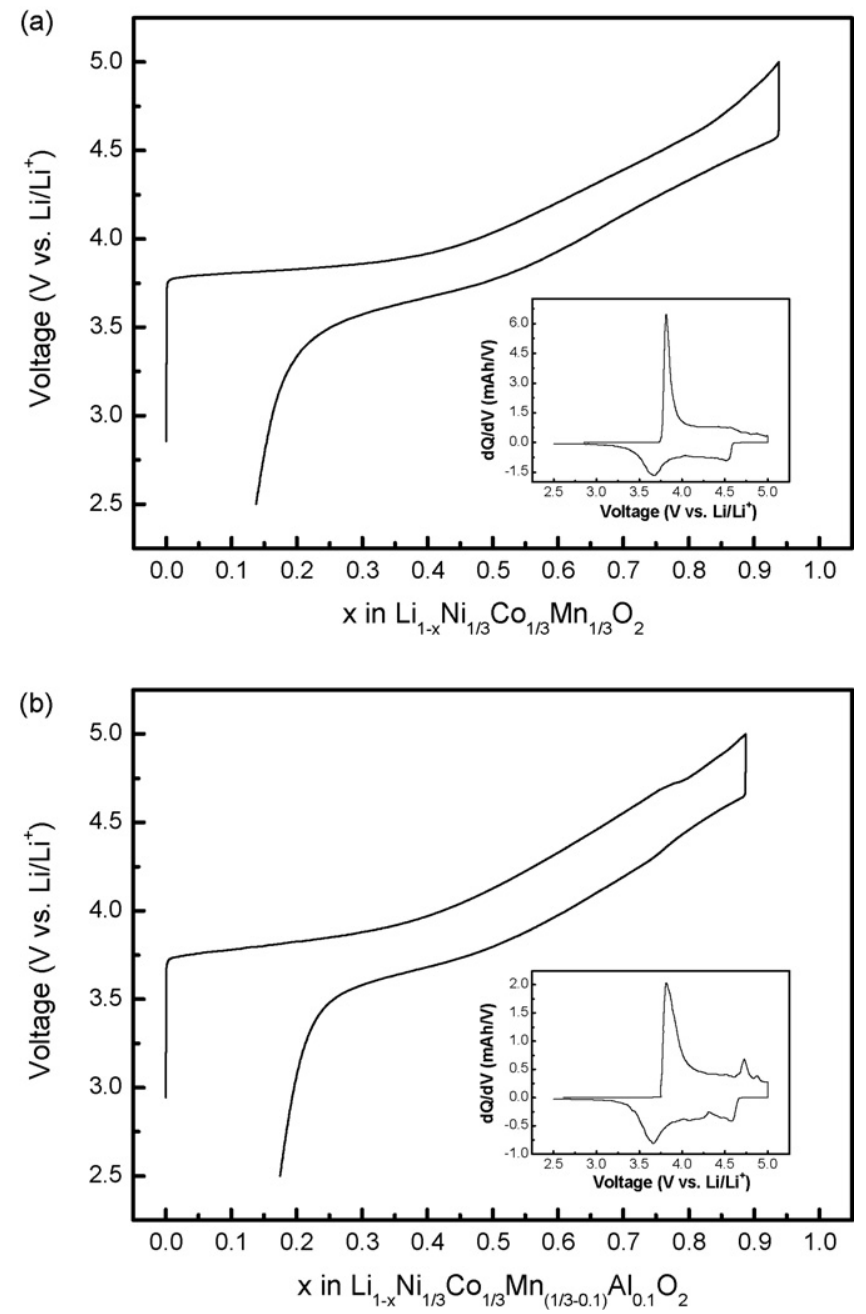

Fig. 7. First charge/discharge curves and differential capacity vs. voltage of $\mathrm{Li} / \mathrm{LiNi}_{1 / 3} \mathrm{Co}_{1 / 3} \mathrm{Mn}_{(1 / 3-y)} \mathrm{Al}_{y} \mathrm{O}_{2}$ cells between $2.5 \mathrm{~V}$ and $5.0 \mathrm{~V}$. (a) $y=0$ and (b) $y=0.1$.

stability could be attributed to aluminum substitution. However, over-substitution by aluminum has adverse effects. The valence change of nickel ions in $\mathrm{LiNi}_{1 / 3} \mathrm{Co}_{1 / 3} \mathrm{Mn}_{1 / 3-y} \mathrm{Al}_{y} \mathrm{O}_{2}$ may have influence on the variation of the redox centers, leading to increased irreversible capacity and altered range of operation voltage of the materials.

Since lithium ions in $\mathrm{LiNi}_{1 / 3} \mathrm{Co}_{1 / 3} \mathrm{Mn}_{1 / 3-y} \mathrm{Al}_{y} \mathrm{O}_{2}$ could not be fully extracted between $2.5 \mathrm{~V}$ and $4.5 \mathrm{~V}$, the upper cut-off voltage was further raised to $5.0 \mathrm{~V}$ to elucidate the charge transfer reactions. The first charge/discharge curves, corresponding to the amount of de-intercalated lithium ions, of $\mathrm{LiNi}_{1 / 3} \mathrm{Co}_{1 / 3} \mathrm{Mn}_{1 / 3-y} \mathrm{Al}_{y} \mathrm{O}_{2}$ cells between $2.5 \mathrm{~V}$ and $5.0 \mathrm{~V}$ with a current density of $20 \mathrm{~mA} / \mathrm{g}$ are depicted in Fig. 7. As shown in Fig. 7(a), $\mathrm{LiNi}_{1 / 3} \mathrm{Co}_{1 / 3} \mathrm{Mn}_{1 / 3} \mathrm{O}_{2}$ charged to $5.0 \mathrm{~V}$ can deliver about $94 \%$ of the total lithium ions. In Fig. 7(b), the sample with $y=0.1$ gives a value of $89 \%$ approximating the fraction of extractable lithium ions (90\%). For the sample with $y=0.2$ as illustrated in Fig. 8(a), about $78 \%$ of the total lithium ions are de-intercalated, revealing that the compound is adequately delithiated at $5.0 \mathrm{~V}$. Once manganese ions are fully replaced by aluminum ions, 2/3 mole fraction of lithium ions can be extracted and de-intercalated at room temperature as shown in Fig. 8(b).

The insets of Fig. 7 illustrate the relations between differential capacity and voltage in the range of $2.5-5.0 \mathrm{~V}$. For $\mathrm{LiNi}_{1 / 3} \mathrm{Co}_{1 / 3} \mathrm{Mn}_{1 / 3} \mathrm{O}_{2}$ as shown in Fig. 7(a), there is only one distinct redox peak at around $3.82 \mathrm{~V}$ indicating the oxidation of nickel
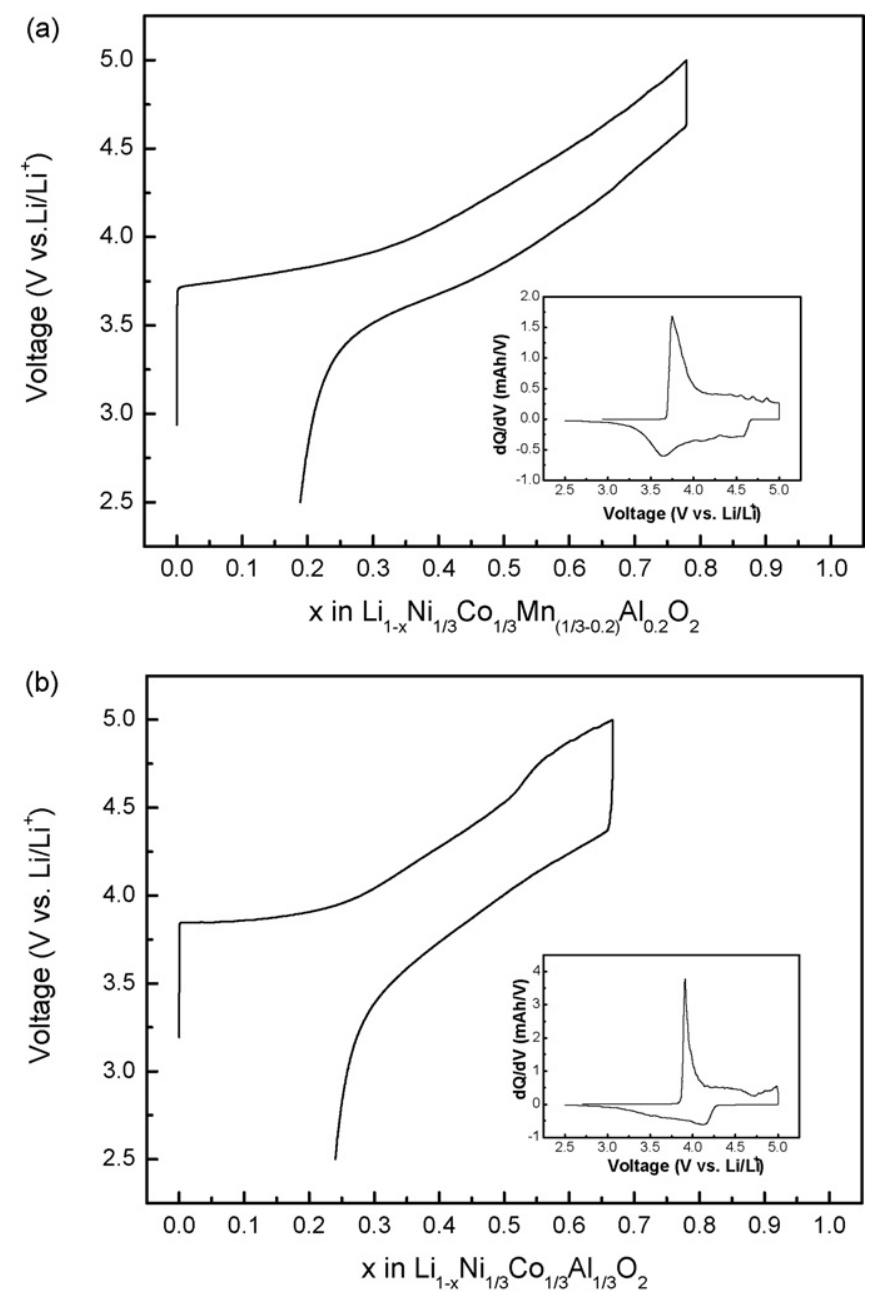

Fig. 8. First charge/discharge curves and differential capacity vs. voltage of $\mathrm{Li} / \mathrm{LiNi}_{1 / 3} \mathrm{Co}_{1 / 3} \mathrm{Mn}_{(1 / 3-y)} \mathrm{Al}_{y} \mathrm{O}_{2}$ cells between $2.5 \mathrm{~V}$ and $5.0 \mathrm{~V}$. (a) $y=0.2$ and (b) $y=1 / 3$.

ions. For the sample with $y=0.1$, one major redox peak related to the oxidation of $\mathrm{Ni}^{2+}$ ions appears at about $3.82 \mathrm{~V}$, and two minor ones probably originated from the phase transition appear at about $4.73 \mathrm{~V}$ and $4.87 \mathrm{~V}$ during the charge process (the inset of Fig. 7(b)). During the discharge process, three redox peaks appear at $3.66 \mathrm{~V}$, $4.08 \mathrm{~V}$, and $4.57 \mathrm{~V}$. As compared with $\mathrm{LiNi}_{1 / 3} \mathrm{Co}_{1 / 3} \mathrm{Mn}_{1 / 3} \mathrm{O}_{2}$, the reduction peak corresponding to $\mathrm{Ni}^{3+} / \mathrm{Ni}^{4+}$ becomes more obvious for the sample with $y=0.1$. This phenomenon may be interpreted by aluminum-ion substitution and altered average valence of nickel ions. For the sample with $y=0.2$ as shown in the inset of Fig. 8(a), one distinct oxidation peak and three reduction peaks are observed during the charge and discharge processes, respectively. However, although two minor oxidation peaks appear in high voltage region, they are much weaker than those in $\mathrm{LiNi}_{1 / 3} \mathrm{Co}_{1 / 3} \mathrm{Mn}_{0.23} \mathrm{Al}_{0.1} \mathrm{O}_{2}$. For $\mathrm{LiNi}_{1 / 3} \mathrm{Co}_{1 / 3} \mathrm{Al}_{1 / 3} \mathrm{O}_{2}$ as shown in the inset of Fig. $8(\mathrm{~b})$, there is only one sharp redox peak at about $3.91 \mathrm{~V}$ corresponding to the oxidation of $\mathrm{Ni}^{3+}$ ions during the charge process. The two oxidation peaks in high voltage region disappear, indicating that the phase transition can be suppressed by increasing the aluminum content. During the discharge process, two weak redox peaks appear at about $4.12 \mathrm{~V}$ and $3.71 \mathrm{~V}$ corresponding to $\mathrm{Co}^{3+} / \mathrm{Co}^{4+}$ and $\mathrm{Ni}^{3+} / \mathrm{Ni}^{4+}$ pairs, respectively. It is found that doping aluminum ions significantly varied the electrochemical properties of $\mathrm{LiNi}_{1 / 3} \mathrm{Co}_{1 / 3} \mathrm{Mn}_{1 / 3} \mathrm{O}_{2}$. 


\section{Conclusions}

$\mathrm{LiNi}_{1 / 3} \mathrm{Co}_{1 / 3} \mathrm{Mn}_{1 / 3-y} \mathrm{Al}_{y} \mathrm{O}_{2}$ has been successfully synthesized via the sol-gel pyrolysis method. The lattice parameters of $\mathrm{LiNi}_{1 / 3} \mathrm{Co}_{1 / 3} \mathrm{Mn}_{1 / 3-y} \mathrm{Al}_{y} \mathrm{O}_{2}$ are found to decrease with increasing content of aluminum ions. XANES demonstrates that the valence of cobalt ions does not change with doping aluminum ions, whereas the oxidation state of partial nickel ions varies from $2+$ to $3+$. The redox centers during the electrochemical reaction are changed by doping aluminum ions from nickel ions alone to both nickel and cobalt ions. The amounts of de-intercalatable lithium ions are affected by the concentration of aluminum ions; however, the extracting efficiency of lithium ions is enhanced by doping aluminum ions. Among the prepared samples, $\mathrm{LiNi}_{1 / 3} \mathrm{Co}_{1 / 3} \mathrm{Mn}_{0.23} \mathrm{Al}_{0.1} \mathrm{O}_{2}$ is found to exhibit the best capacity retention and the least irreversible capacity.

\section{References}

[1] N. Yabuuchi, T. Ohzuku, J. Power Sources 171 (2003) 119-120.

[2] K.M. Shaju, G.V.S. Rao, B.V.R. Chowdari, Electrochim. Acta 48 (2002) 145151.

[3] B.J. Hwang, Y.W. Tsai, D. Carlier, G. Ceder, Chem. Mater. 15 (2003) 3676-3682.

[4] H. Kobayashi, Y. Arachi, S. Emura, K. Tatsumi, Solid State Ion. 178 (2007) 1101-1105.

[5] B. Zhang, G. Chen, P. Xu, C.C. Li, J. Power Sources 176 (2008) 325-331.

[6] C.H. Lu, R. Jagannathan, Appl. Phys. Lett. 80 (2002) 3608-3610.

[7] C.H. Lu, H.C. Hong, R. Jagannathan, J. Mater. Sci. Lett. 21 (2002) 1489-1492.

[8] T. Ohzuku, A. Ueda, M. Kouguchi, J. Electrochem. Soc. 142 (1995) 4033-4039.

[9] L.E. Shea, J. McKittrick, O.A. Lopez, J. Am. Ceram. Soc. 79 (1996) 3257-3265.

[10] W.S. Yoon, C.P. Grey, M. Balasubramanian, X.Q. Yang, D.A. Fischer, J. McBreen, Electrochem. Solid State Lett. 7 (2004) A53-A55.

[11] Y. Koyama, I. Tanaka, H. Adachi, Y. Makimura, T. Ohzuku, J. Power Sources 644 (2003) 119-121.

[12] Y.K. Lin, C.H. Lu, H.C. Wu, M.H. Yang, J. Power Sources 146 (2005) 594-597.

[13] M.K. Aydinol, A.F. Kohan, G.J. Ceder, K. Cho, J. Joannopoulos, Phys. Rev. B 56 (1997) 1354-1365.

[14] Y.I. Jang, B. Huang, H. Wang, G.R. Maskaly, G. Ceder, D.R. Sadoway, Y.M. Chiang, H. Liu, H. Tamura, J. Power Sources 589 (1999) 81-82. 